\title{
Heating by Flat Plate Collector Combined with a Heat Pump
}

\author{
Simon Marčič 1 - Sebastijan Seme ${ }^{1}$ - Julijan Jan Salamunić1 - Zdravko Praunseis ${ }^{1}$ - Stanislav Pehan ${ }^{2}$ \\ ${ }^{1}$ University of Maribor, Faculty of Energy Technology, Slovenia \\ 2 University of Maribor, Faculty of Mechanical Engineering, Slovenia
}

\begin{abstract}
The aim of the research was to establish the efficiency of the combination flat plate collector-heat pump versus ambient air-heat pump. The extensive measurements were carried out and analyzed of the flat plate collector alone and combination flat plate collector-heat pump. In the beginning, the heat pump introduction into the serial combination with flat plate collectors was analyzed. The appropriate test rig with measurement equipment was designed and built. The test rig base consisted of the flat plate collector, heat pump, and 300 I boiler that was a replacement for a house's heating. Detailed temperature measurements were performed during rainy, sunny and cloudy weather in summer and winter. To estimate the efficiency of heating, the consumed electric energy versus heat is the universal criterion that is derived from the Coefficient of performance (COP), which is calculated on the basis of measured temperatures. The comparison of the calculated COP for the combination flat plate collector-heat pump and the air-water heat pump shows that the largest increase of the COP of the combination flat plate collector-heat pump in comparison with the air-water heat pump is on sunny winter days, and that it amounts to $38 \%$. In rainy and cloudy weather, the COP of the flat plate collector-heat pump combination is lower than the air-water heat pump COP. The presented analyses clearly indicated that use of the flat plate collector is limited.
\end{abstract}

Keywords: flat plate collector, heat pump, the Coefficient of performance, test rig

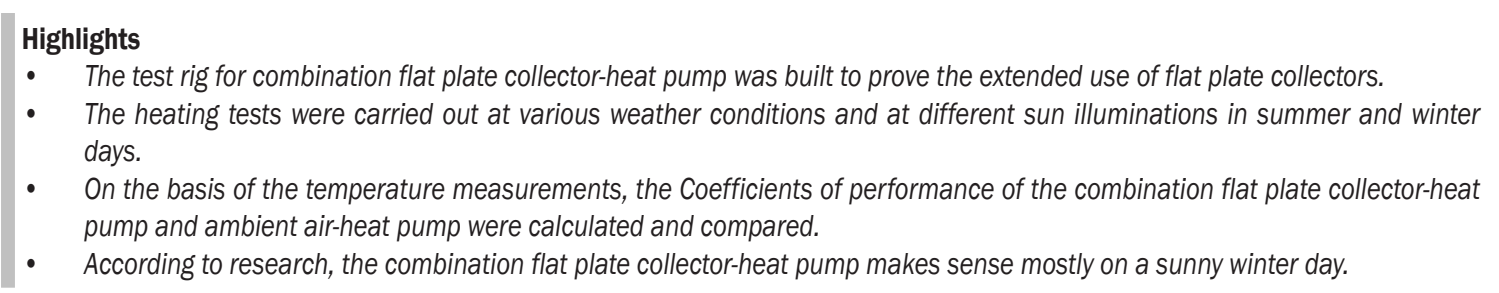

\section{INTRODUCTION}

Recently, many houses have been equipped with solar collectors in order to ensure the sanitary hot water and heat. Nowadays, the heating systems based on heat extraction from the ambient air have become more efficient and, in particular, cheaper. The question arises as to whether the systems with solar collectors should be really entirely written-off, or whether they could, nevertheless, be upgraded sensibly and effectively.

The basic goal of the presented research work was to find a way to raise the heating capacity of a heating system that is based on solar collectors [1] and [2]. The second goal was to present the theoretical reasons that would convince the owners and the investors to preserve, and even upgrade, the existing house heating systems with solar collectors to provide a longer heating season.

The key component of active solar heating systems are the solar collectors that gather the sun's energy, transform this into heat, and then transfer that heat to a fluid, usually water. Mainly two types of solar collectors are used presently: Flat plate collectors [3] and [4] and evacuated tube collectors [5] to [7]. Flat plate collectors usually consist of a glass cover and metal plate absorber with the integrated pipes and housing. The solar energy absorbed by the metal plate absorber is transferred into the liquid flowing within the pipes. The glazing on the upper surface and the insulated housing bottom limit the thermal losses. In the flat plate collector, in the gap between the glazing and the metal plate absorber, the air is present. From the metal plate absorber, this air is warmed, then heats the glazing and becomes the source of losses. To avoid this harmful phenomenon, the so-called evacuated tube collectors have been introduced. They consist of glass evacuated tubes, through which the absorption pipes are installed [8] and [9].

The evacuated tube collectors are more effective but, in comparison with heat pumps, both types of collectors alone in the long-term are losing heat. For domestic heating and domestic hot water gathering a heat pump alone [10] to [12] is used increasingly. They are much more effective than simple electrical resistance heaters using the same amount of electricity [13] to [14]. Heat pumps are designed to move the thermal energy in the opposite direction of spontaneous heat transfer by absorbing heat (anergy) from a cold space and releasing it to a warmer one. To 
run the compressor, a heat pump uses a small amount of external electric energy (exergy). The source of anergy can be any surrounding media; air, water etc. To describe the ratio of the heat flow (anergy plus exergy) and external electric energy (exergy), the term Coefficient of performance (COP), is used. Theoretically, the COP increases when the temperature difference between the cold space and the warmer one decreases. That fact encourages the heating designer to choose low-temperature underfloor house heating rather than high-temperature radiators [15] and [16].

Conventionally, all types of collectors and heat pumps are used separately. In the paper, it is a suggestion to join both systems in a serial connection. Heated water that is coming from the collector is led directly into the input side of a heat pump to gain the higher temperatures. Hypothetically, this serial connection should ensure higher temperatures of heating as each heating system works independently.

To verify the effectiveness of the serial connection flat plate collector - heat pump, a convenient test rig was built on a reduced scale. Measurements of suitable quantities were carried out and analyzed. The test rig consists of a flat plate collector, water-water heat pump, and boiler. The boiler is a replacement for house heating. The water in the boiler accumulates the heat that is produced over the day.

The tests were carried under various weather conditions in the summer and winter seasons. Inlet and outlet temperatures from the flat plate collector and heat pump were measured, as well as the ambient air temperature and the water temperature in the boiler.

The paper comprises the testing of the flat plate collector alone and combination flat plate collectorheat pump. The purpose of this test is to establish the efficiency of each system. Comparisons of both systems were carried out.

\section{HEATING BY FLAT PLATE COLLECTOR}

The dedicated test facility is shown in Fig. 1. On the building roof, several flat plate collectors are positioned oriented to the south. The flat plate collector positioned on the left side of the roof that is tested has an active absorber area of two square meters.

The boiler, capacity 300 liters, is located in the building. The flat plate collector heats the boiler water directly by adequate heat exchanger built in the boiler. Basic flat plate collector characteristics are follows: 2 square meter active surface, copper absorber with special selective layer, crystal prism glass, housing made from anodized aluminum, rock wool isolation, four pipe connections and steam flap. The measurement schema is shown in Fig. 2.

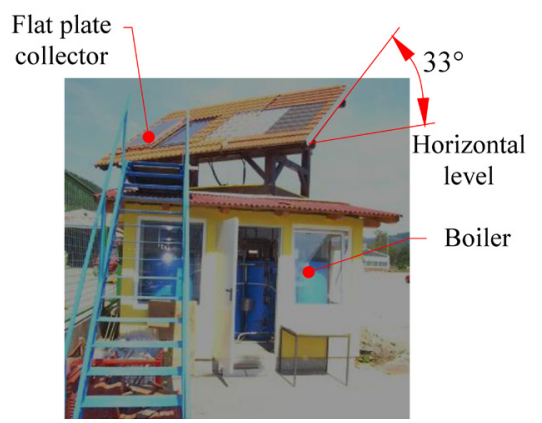

Fig. 1. Test facility

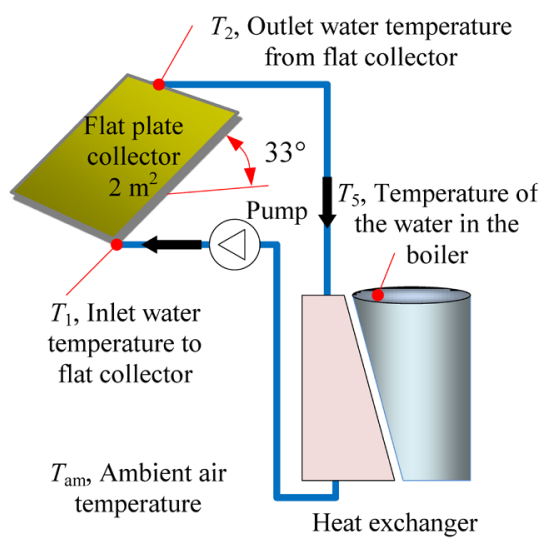

Fig. 2. Measurement schema of heating boiler water by flat plate collector

Measurements, Figs. 3 and 4, show that in cloudy and rainy weather, the efficiency of the flat plate collector is low. In cloudy weather, the water temperature in the boiler $T_{5}$ is mostly lower than the temperature of the ambient air during the measurement process. In cloudy weather, the contribution of diffusion light to effective heating is low. This phenomenon is in accordance with the measurements of the illumination, which was, in perfectly clear weather, from 90,000 Lux to 95,000 Lux, and in the cloudy from 3,000 Lux to 5,000 Lux.

\section{HEATING BY SERIAL CONNECTION FLAT PLATE COLLECTOR-HEAT PUMP}

Flat plate collector is in serial connection with the heat pump water-water, $1.5 \mathrm{~kW}$ under standard measurement conditions, Fig. 5.

A comparison of heating with a flat plate collector and a combination flat plate collector-heat pump shows the obvious advantage of the latter, Fig. 6 . With the system, even in the most unfavorable weather 


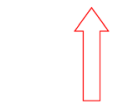

Temperature

$\left[{ }^{\circ} \mathrm{C}\right]$

(Measured at

$15: 40$ p.m.)

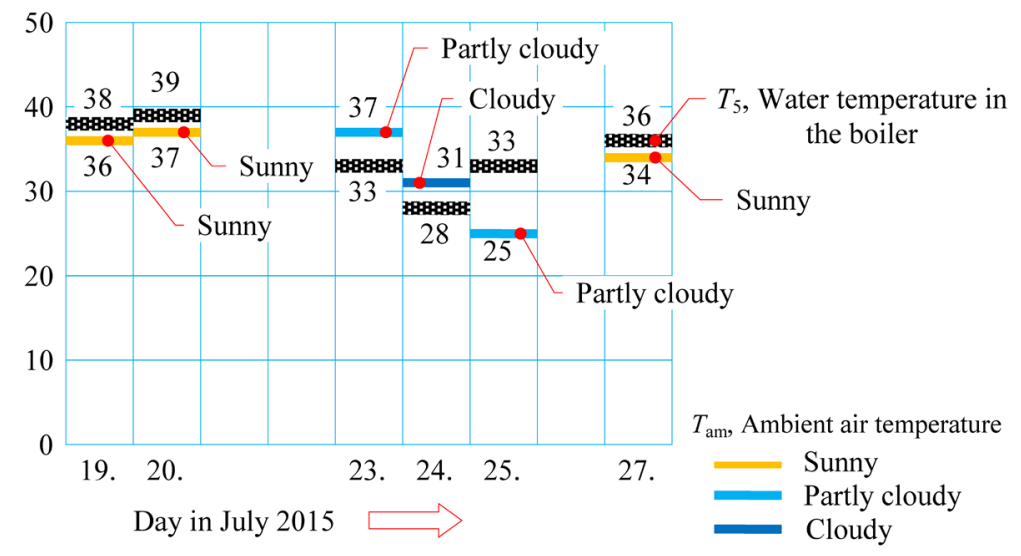

Fig. 3. Temperatures in the boiler by heating with flat plate collector in July 2015

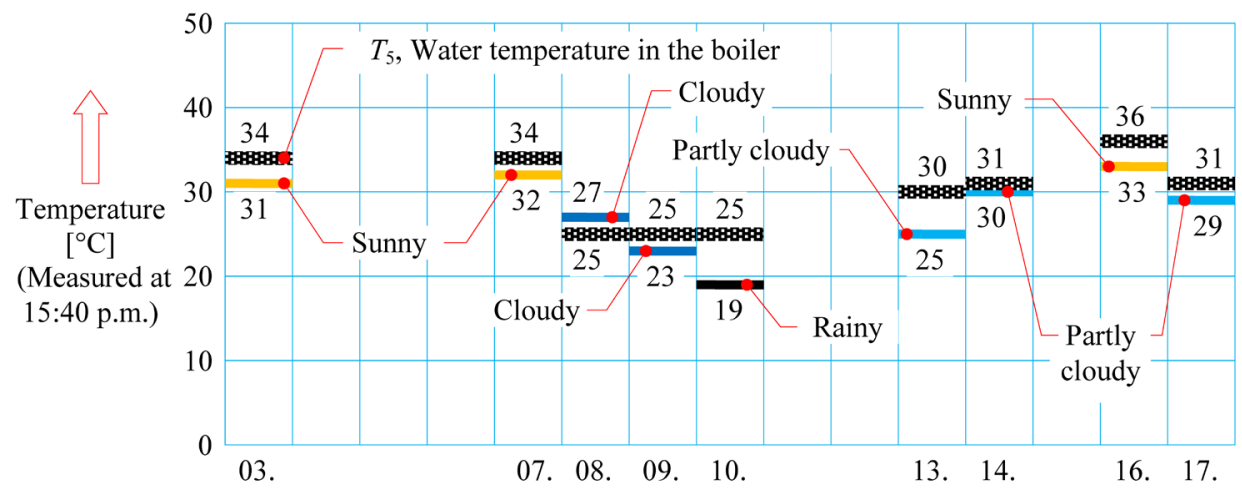

Day in August $2015 \square$ Ambient temperatures

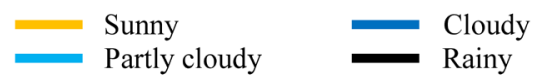

Fig. 4. Temperatures in the boiler by heating with flat plate collector in August 2015

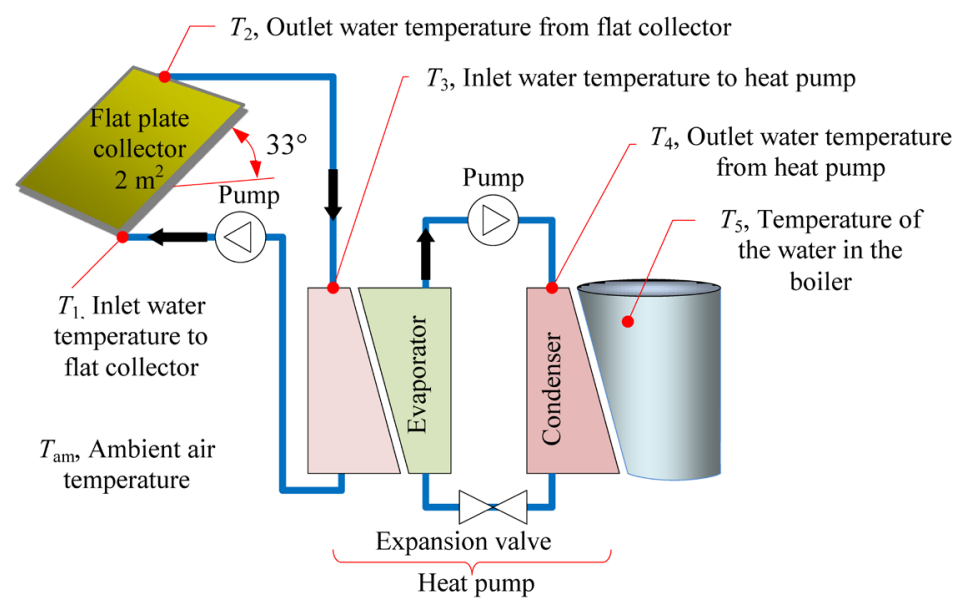

Fig. 5. The setup of the boiler water heating by the combination flat collector-heat pump

conditions, high temperatures can be achieved in the boiler. On a rainy day, for example, only flat plate collectors heat the water in a boiler from $19{ }^{\circ} \mathrm{C}$ to about $25{ }^{\circ} \mathrm{C}$, and the combination is from $18{ }^{\circ} \mathrm{C}$ to about $39^{\circ} \mathrm{C}$. 


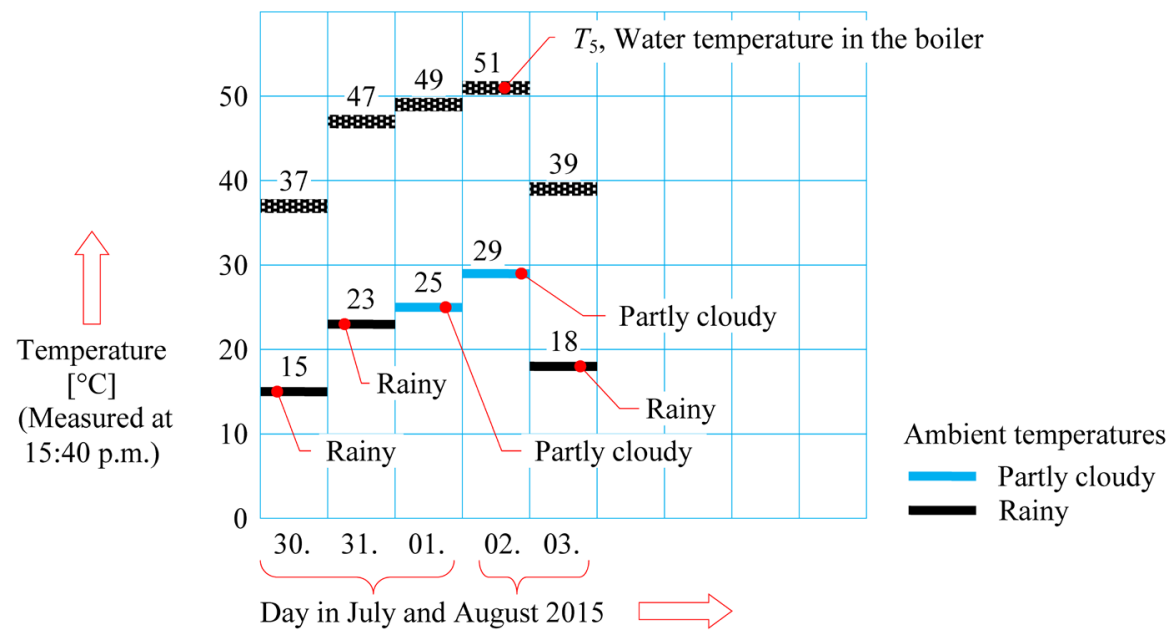

Fig. 6. Temperature in the boiler as a result of heating with flat plate collector-heat pump

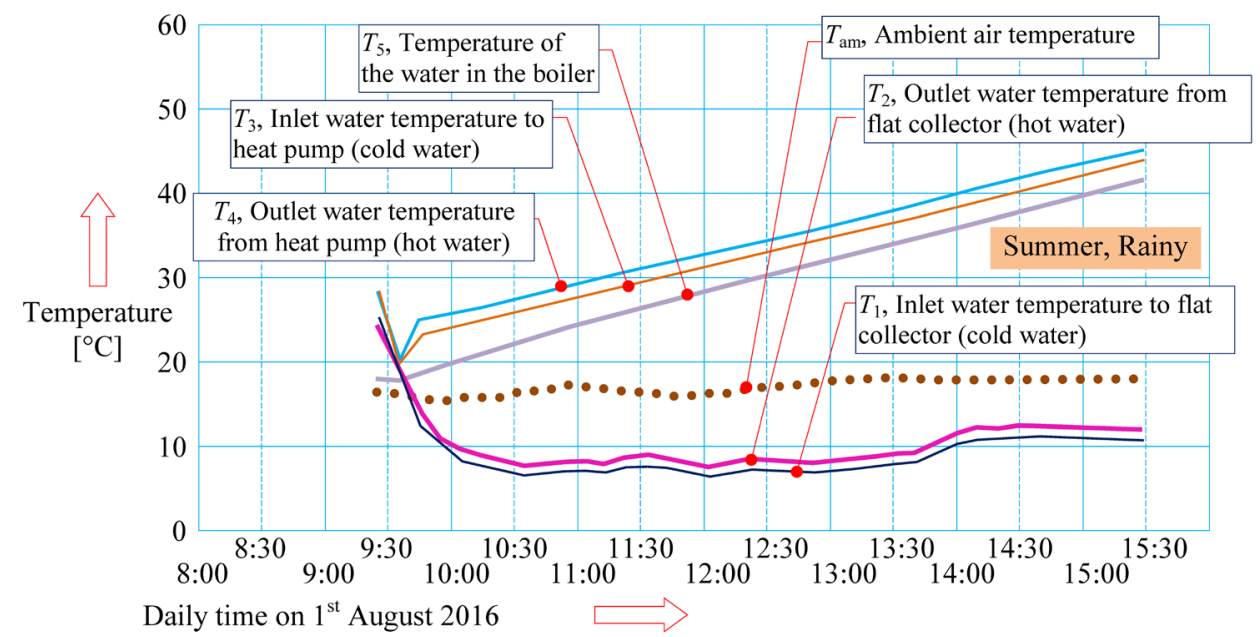

Fig. 7. Temperatures in the heating system, of the flat collector and the heat pump, on a rainy summer day

\section{FLAT PLATE COLLECTOR-HEAT PUMP VERSUS AMBIENT AIR-HEAT PUMP}

To understand the functioning of the flat plate collector-heat pump, it is worthwhile to know more precisely the generation of heat energy over the entire current day. Therefore, temperature measurements were carried out at the characteristic points of the heating system, every 10 minutes, from 9:30 to 15:30.

The temperature of the water at the inlet and at the outlet from the flat plate collector and at the inlet and at the outlet of the heat pump, the boiler temperature, and the ambient air temperature are measured. In the following figures, Figs. 7 to 11, the measurements of temperatures are presented in three summer and two winter days, in order to see the operation of the heating system in extreme cases.

From Fig. 7 it follows that, on a rainy summer day, the ambient air temperature is higher than the temperatures in the flat plate collector, as a result of the low illumination. The contribution of the diffusion light is too small to warm the water at a higher temperature than the ambient air. At the beginning of the measurement, at 9:30, the temperatures $T_{1}$ and $T_{2}$ are higher than the ambient air temperature because the system is stationary and there is no water flow. In the stationary state, diffusion light radiation can heat the water above the temperature of the ambient air.

At the beginning of the measurement, Fig 8, when there is no water flow in the system, the inlet and the outlet temperatures $T_{1}$ and $T_{2}$ are higher than 


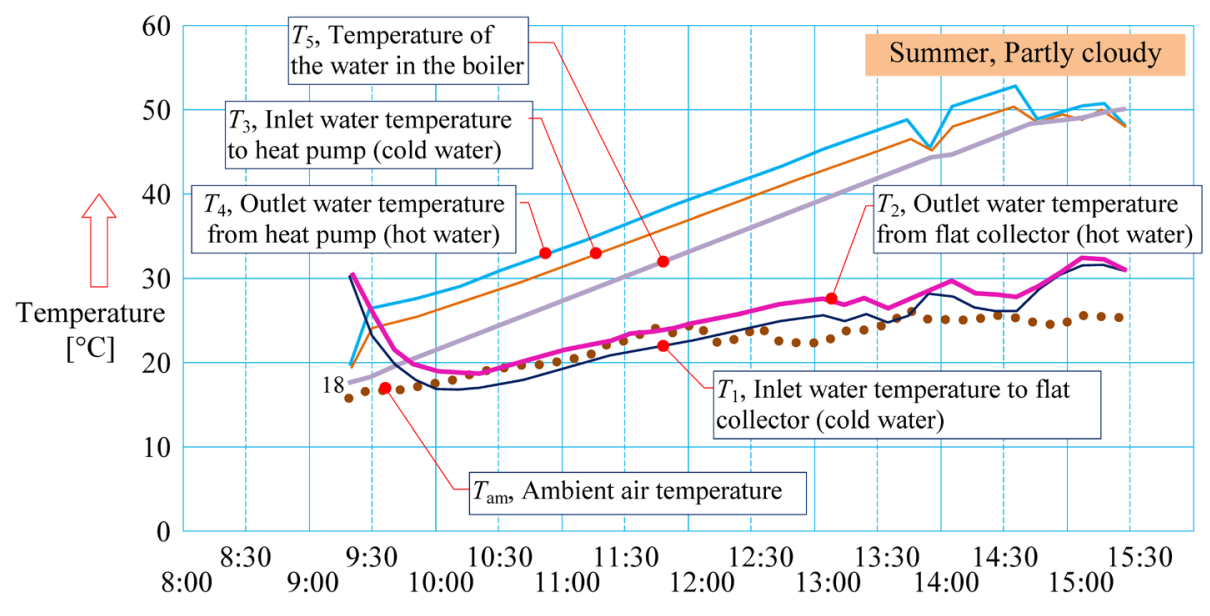

Daily time on $2^{\text {nd }}$ August $\quad \longrightarrow$

Fig. 8. Temperatures in the heating system, of a flat plate collector and heat pump, on a partly cloudy summer day

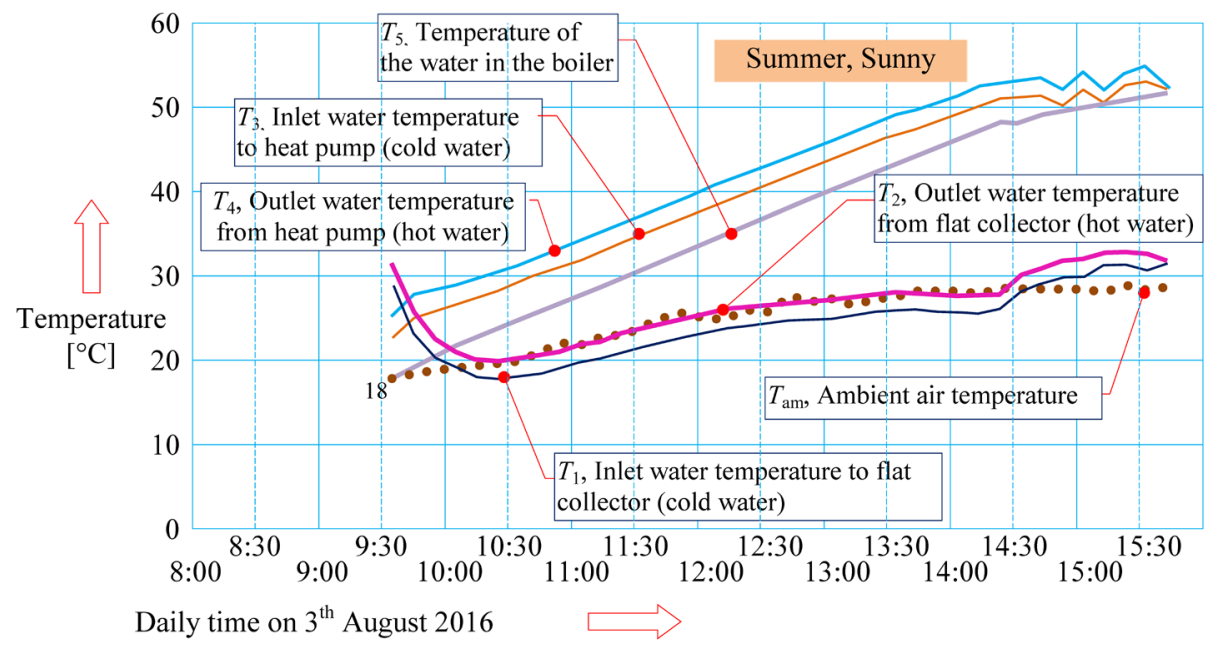

Fig. 9. Temperatures in the heating system of a flat plate collector and heat pump, on a sunny summer day

the ambient air by $14{ }^{\circ} \mathrm{C}$. By noon the cloudy weather prevailed, after that the weather became mostly clear. By 12:00 the outlet water temperature $T_{2}$ is equal to or two degrees Celsius higher than the ambient air. After 12:00, when the weather became mostly clear, the temperatures $T_{1}$ and $T_{2}$ exceeded the ambient air temperature. The largest surplus is $7{ }^{\circ} \mathrm{C}$ at $15: 15$.

Fig. 9 shows the course of temperatures in the misty sunny weather when the illumination did not exceed 55,000 Lux. After the circulation pumps switched on, the outlet water temperature $T_{2}$ was equated with the temperature of the ambient air and, till 14:30, remained practically the same. After the sunlight dispersed the mist, the temperatures $T_{1}$ and $T_{2}$ became higher than the ambient air $T_{\text {am }}$ by about $5^{\circ} \mathrm{C}$.
Fig. 10 shows the course of temperature and brightness on December 29th, 2015. Illumination varied between 49,000 Lux and 63,000 Lux. In the stationary state, when there is no flow, water (a mixture of glycol and water) in the flat plate collector was warmed up to $18{ }^{\circ} \mathrm{C}$ higher temperature than the ambient air. After the circulation pumps were switched on, the temperatures $T_{1}$ and $T_{2}$ were equalized to the temperature $T_{\mathrm{am}}$. As the illumination increases and, above all, because of the rise of the Sun above the horizon, the incidence angle of light towards the flat plate collector increases, so more light falls on the flat plate collector. The highest difference between the outlet water temperature $T_{2}$ and the ambient air temperature $T_{\mathrm{am}}$ was $9{ }^{\circ} \mathrm{C}$, at $12: 30$, when the Sun 


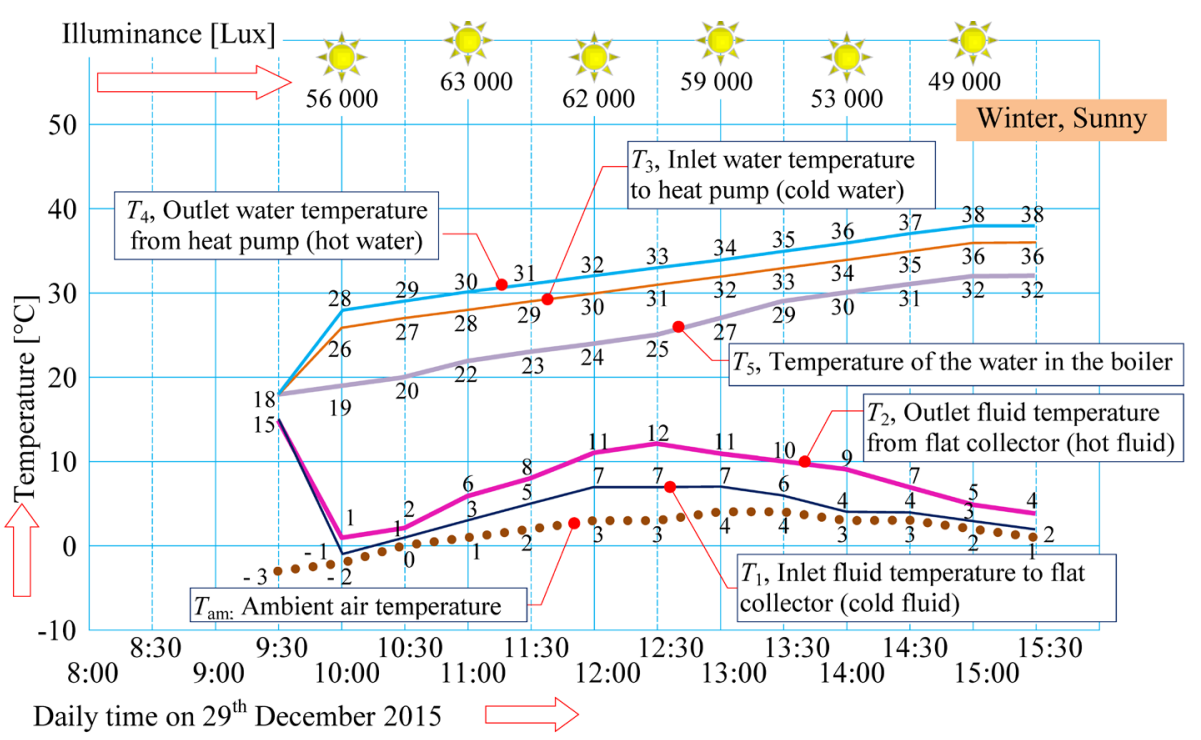

Fig. 10. The ambient illuminance and the temperatures in the heating system of a flat plate collector and heat pump, on a sunny winter day

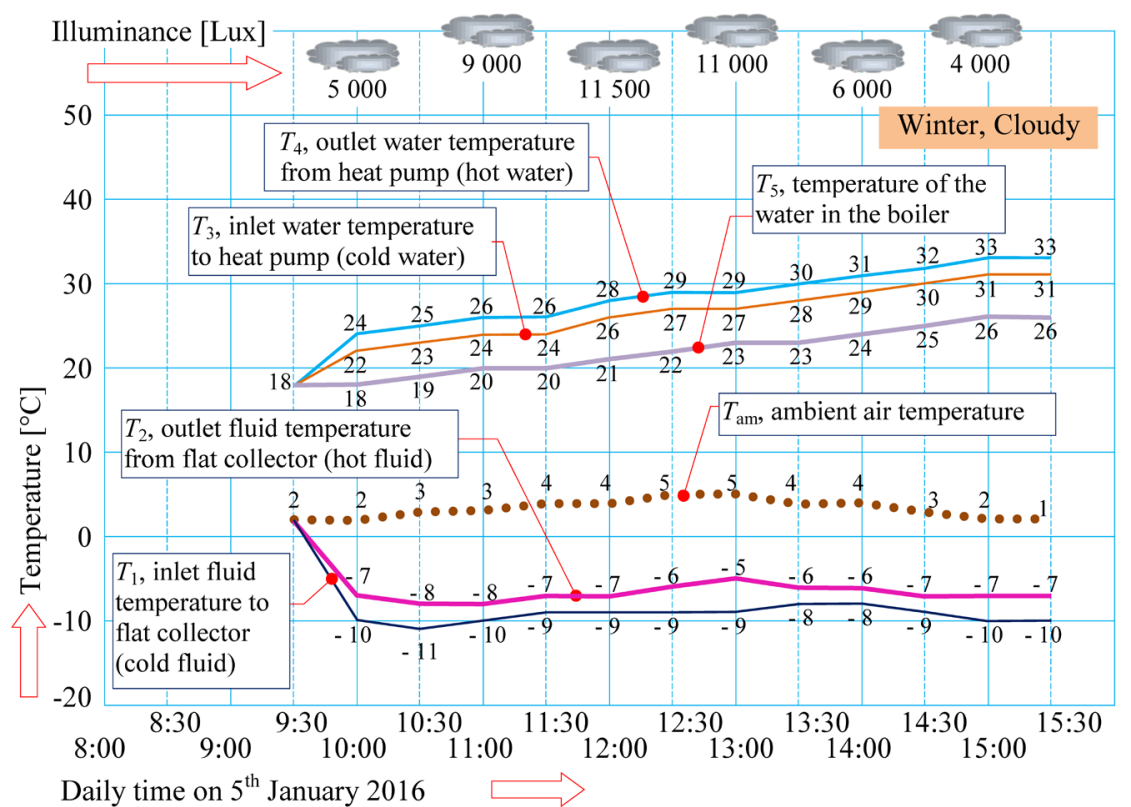

Fig. 11. The ambient illuminance and the temperatures in the heating system, of a flat plate collector and heat pump, on a cloudy winter day

was in the highest position, and then the temperature difference began to decrease, and it was, at 15:30, only $2{ }^{\circ} \mathrm{C}$.

At the beginning of the measurements, Fig. 11, at 9:30, when the circulation pump was stationary and the illumination was low, the temperatures $T_{1}$, $T_{2}$, and $T_{\mathrm{am}}$ were the same. The inlet $T_{3}$ and the outlet temperature $T_{4}$ of the heat pump were the same as the water temperature in the boiler $T_{5}$. After the circulation pumps were switched on, the outlet water temperature from the flat plate collectors $T_{2}$ is reduced by an average amount of $10{ }^{\circ} \mathrm{C}$. Lowering the temperature was due to the lower illumination. The flat plate collector received the heat from the diffusion light, the portion of which was low, and from the heat transfer, which was low also due to the good insulation.

On the basis of the temperature measurements and exergetic efficiency $\xi$, given by the heat pump manufacturer, COP is calculated using the following equation: 


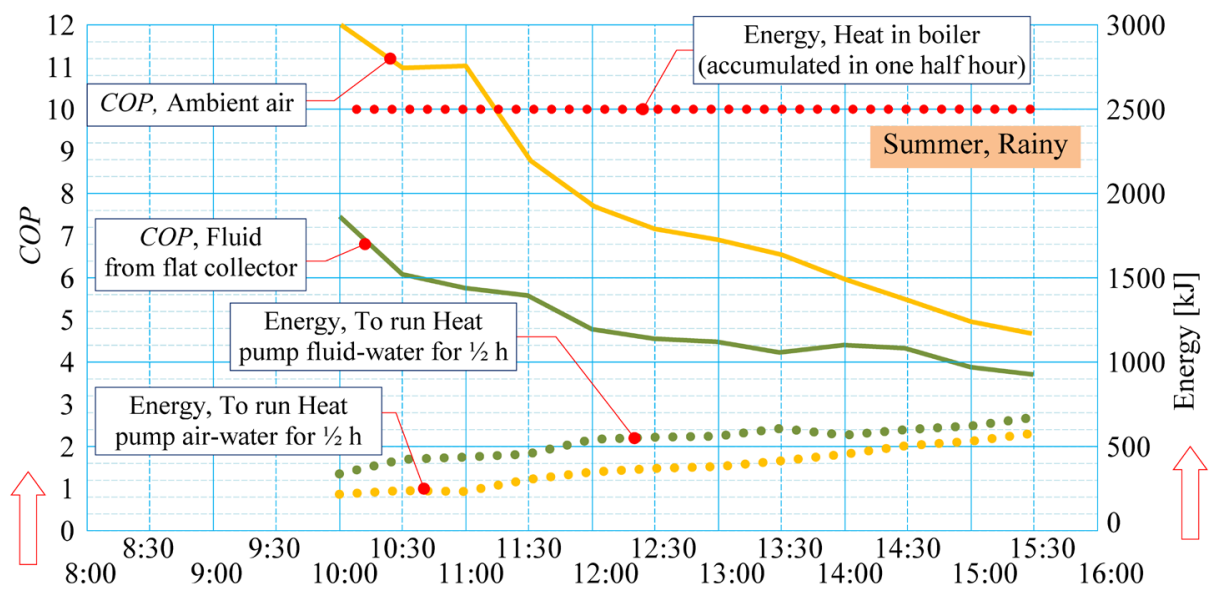

Daily time on $1^{\text {st }}$ August $2016 \longrightarrow$

Fig. 12. The COP and energies in the heating system with the heat pump on a rainy summer day

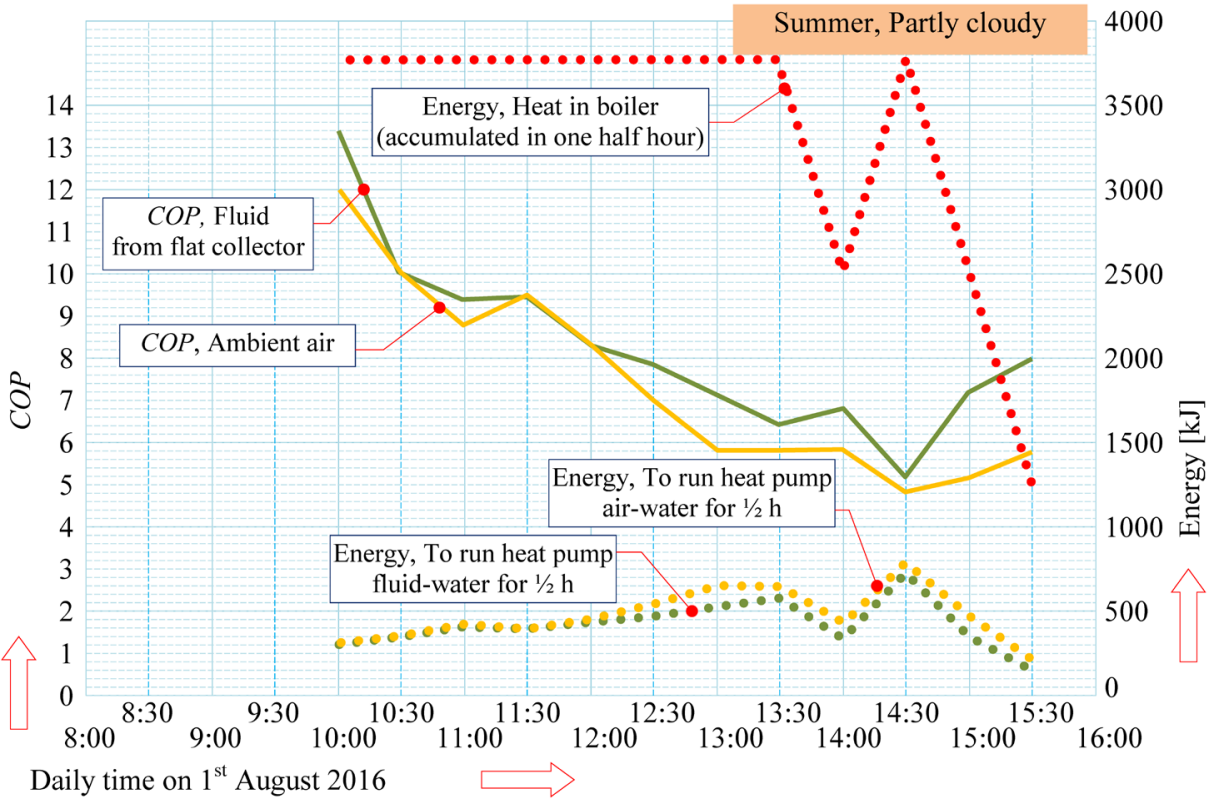

Fig. 13. The COP and energies in the heating system with the heat pump on a partly cloudy summer day

$$
\mathrm{COP}=\frac{T_{4}}{T_{4}-T_{2}} \cdot \xi,
$$

where $T_{4}$ is the heat pump outlet water temperature and $T_{2}$ is the temperature the of the heating anergy. In the case of the air-water heat pump, the $C O P$ is calculated by the following equation

$$
C O P=\frac{T_{4}}{T_{4}-T_{a m}} \cdot \xi,
$$

where $T_{\mathrm{am}}$ stands for ambient temperature.
The purpose of the flat plate collector-heat pump combination testing is to establish under what weather conditions this combination is better than a conventional air-water heat pump. Heat generated by both systems is calculated using the equation

$$
Q=m \cdot c_{w} \cdot\left(T_{5}-T_{5 i n t}\right),
$$

where $Q$ is the generated heat, $m$ is the mass of water in the boiler, $c_{w}$ is specific water heat, $T_{5}$ is the actual temperature of the water in the boiler, and $T_{5 i n t}$ is the initial water temperature in the boiler $\left(18^{\circ} \mathrm{C}\right)$. Eq. 


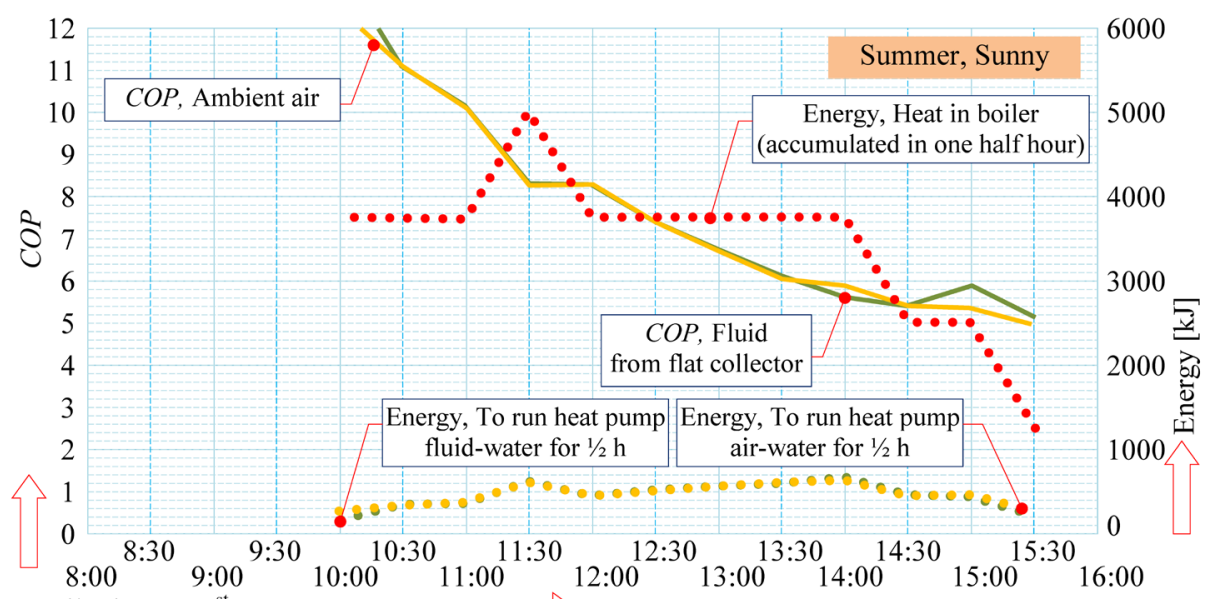

Daily time on $1^{\text {st }}$ August 2016

Fig. 14. The COP and energies in the heating system with the heat pump on a sunny summer day

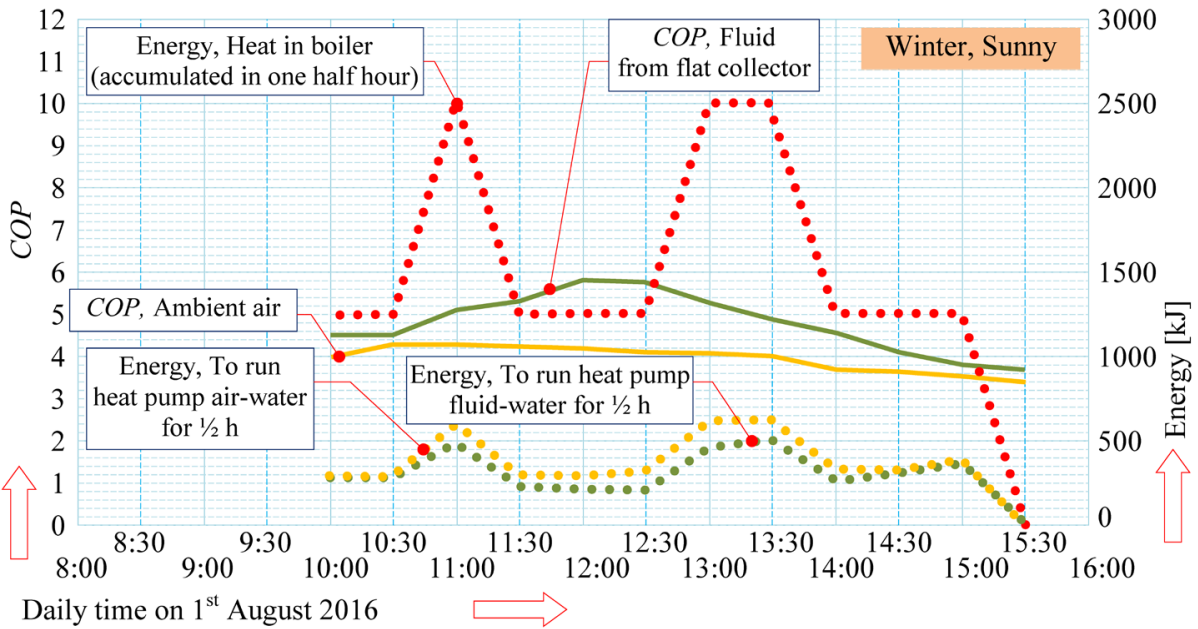

Fig. 15. The COP and energies in the heating system with the heat pump on a sunny winter day

(3) is used to calculate the actually generated heat accumulated in the boiler. Subsequently, by means of the COPs calculated by Eqs. (1) and (2) the heating exergy or electric energy consumed by both heat pumps is calculated.

Fig. 12 shows the calculated COPs for flat plate collector-heat pump combination and air-water heat pump. Given that, in rainy summer weather, the outlet temperature from the flat plate collector $T_{2}$ is lower than the ambient air temperature $T_{\mathrm{am}}$, the COPs for the flat plate collector-heat pump combination are lower than the COP of the air-water heat pump. As a result, the heating exergy of the flat plate collector-heat pump combination is higher than the air-water heat pump heating exergy. In other words, to heat the water to the same temperature $T_{5}$, the flat plate collector-heat pump combination consumes more electric energy than the air-water heat pump.

If the weather is changeable or partly cloudy, Fig. 13 shows that the COP of the flat plate collector-heat pump combination is better than of the air-water heat pump by $3 \%$ at $11: 30$ and by $33 \%$ at $15: 30$. Moreover, the consumption of electric energy or exergy of the flat plate collector-heat pump combination is correspondingly lower than that of the air-water heat pump.

If it is a hazy and sweltering sunny day, Fig. 14, the COP of the flat plate collector-heat pump combination is, on average, higher by $4 \%$ between $9: 30$ and 14:30 than of the air-water heat pump, but at 15:00 it rises to $19 \%$. The consumption of the electric energy of the flat plate collector-heat pump combination decreases 


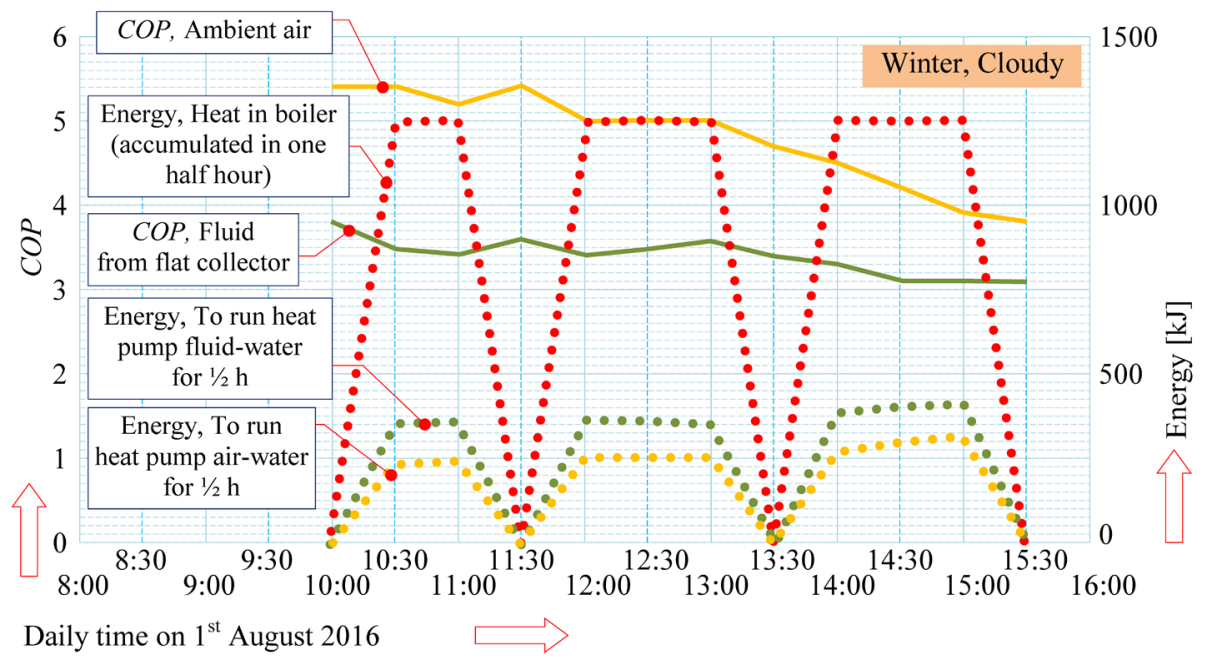

Fig. 16. The COP and energies in the heating system with the heat pump on a cloudy winter day

in the same portion. The increase of COP and lower electric energy consumption result from the clearer weather. The sun dispersed the mist covering the sky until then.

The greatest improvement of the COP of the flat plate collector-heat pump combination in comparison with the air-water heat pump occurs in sunny winter weather, Fig. 15, and amounts to as much as $38 \%$ at 12:30. The smallest improvement is at 15:30 and amounts to $17 \%$. Such improvements result from a low ambient air temperatures $T_{\mathrm{am}}$ and, consequently, from the low proportion of the heating energy in the heating thermal energy. In winter months when the ambient air temperatures $T_{\mathrm{am}}$ are low, the airwater heat pump must overcome wider temperature differences to achieve the same temperature of the heated water as on summer days, resulting in low COPs. Likewise, the consumption of electric energy of the flat plate collector-heat pump combination is reduced in comparison with the air-water heat pump.

On cloudy winter days when the illumination is low, Fig. 16, the COP of the flat plate collector-heat pump combination is worse than the COP of the airwater heat pump. The flat plate collector fails to heat the water that is circulating in the collector-evaporator system, Fig. 5, of the heat pump of the flat plate collector-heat pump combination, to a temperature higher than the ambient air temperature $T_{\mathrm{am}}$. The flat plate collector receives heat from diffusion light, which is very low. Consequently, the heat transfer by convection from the ambient air to the absorption flat plate collector is very low also. The electric energy consumption of the flat plate collector-heat pump combination is also increased accordingly in comparison with the air-water heat pump.

\section{RESULTS AND DISCUSSION}

On sunny summer days, the solar collector heated the boiler water to a temperature from $34{ }^{\circ} \mathrm{C}$ to $36{ }^{\circ} \mathrm{C}$. In cloudy and rainy weather, the boiler water temperature was always lower than the ambient air temperature and amounted to $19{ }^{\circ} \mathrm{C}$ in rainy weather and to a temperature from $23{ }^{\circ} \mathrm{C}$ to $27{ }^{\circ} \mathrm{C}$ in cloudy weather. In sunny weather, water is heated to $51^{\circ} \mathrm{C}$ by using the flat plate collector-heat pump combination, up to $29^{\circ} \mathrm{C}$ in partly cloudy weather, and to $19^{\circ} \mathrm{C}$ in rainy weather. In sunny and partly cloudy weather, the flat plate collector-heat pump combination achieves considerably higher temperatures than the solar collectors.

Figs. 7 to 11 show the trend of characteristic temperatures between 9:30 and 15:30 on different summer and winter days and under various weather conditions. The ambient air temperature $T_{\mathrm{am}}$ and water outlet temperature from collectors $T_{2}$ are the most important temperatures. In sunny weather, $T_{2}$ is always higher than $T_{\text {am }}$. The biggest difference between these two temperatures is on a sunny December day, and it amounts to $9{ }^{\circ} \mathrm{C}$. In rainy and cloudy weather, temperature $T_{2}$ is lower than $T_{\mathrm{am}}$. The biggest undercooling is in January and amounts to $11{ }^{\circ} \mathrm{C}$.

The comparison of the calculated COPs for the flat plate collector-heat pump combination and the heat pump air-water system shows that the largest 
increase of the COP of the flat plate collector-heat pump combination in comparison with the air-water heat pump is on sunny winter days and that it amounts to $38 \%$, Fig. 15 . In rainy and cloudy weather, the COPs of the flat plate collector-heat pump combination are lower than the air-water heat pump COPs. The consumption of electric energy follows the COPs strictly, Table 1.

Table 1. Energy - obtained and consumed

\begin{tabular}{|c|c|c|c|c|c|}
\hline & \multicolumn{3}{|c|}{ Summer } & \multicolumn{2}{|c|}{ Winter } \\
\hline & Sunny & $\begin{array}{l}\text { Partly } \\
\text { cloudy }\end{array}$ & Rainy & Sunny & Cloudy \\
\hline $\begin{array}{l}\text { Energy in boiler } \\
\text { [kWh] }\end{array}$ & 11.498 & 11.149 & 8.362 & 4.878 & 2.787 \\
\hline $\begin{array}{l}\text { Heat pump, energy } \\
\text { from ambient air } \\
{[\mathrm{kWh}]}\end{array}$ & 1.543 & 1.585 & 1.190 & 1.223 & 0.588 \\
\hline Average COP & 7.5 & 7.0 & 7.0 & 4.0 & 4.7 \\
\hline $\begin{array}{l}\text { Heat pump, energy } \\
\text { from flat plate } \\
\text { collector [kWh] }\end{array}$ & 1.501 & 1.416 & 1.772 & 1.004 & 0.827 \\
\hline Average COP & 7.7 & 7.9 & 4.7 & 4.9 & 3.4 \\
\hline
\end{tabular}

\section{CONCLUSIONS}

The main novelty of the work is the clarification about the usefulness of the flat plate collectors for most effective and competitive domestic heating. In short, these devices are for write off. This radical statement is based on quite comprehensive measurements of flat plate collectors functioning at different weather condition in summer and winter as the heat provider, that bringing the sun energy in form of heat to the heat pump. The competitors of them have been the ambient air, as it is.

Normally, as the majority of the authors are dealing with, the bivalent system of flat plate panel and the heat pump was designed. In order to improve the efficiency of the heating as best that can be done, in this research, the serial connection of flat plate collector and the heat pump is made and tested. Due to the allegedly higher temperature input into the heat pump, from the serial connection hypothetically the evident improvements of the heating has been expected.

Instead of dealing with the real house heating system, in the experiment the daily collected heat was gathered by using the water boiler, the capacity of 300 liters, that proved to be the very useful and practical idea. The most obvious advantage was the relatively simple test rig design, which does not include any unnecessary systems. An additional advantage was the simplicity of energy measurement that is carried out by using the thermometers only. All the rest was done by simple computations, which could be easy to control. The major disadvantage of these simple experiments represents the absolute values of COPs. In comparison with the generally expected values, COPs obtained in the presented tests, were suspiciously high. This phenomenon was not due to the excellence of the system components, more due to the relatively lowtemperature differences of the boiler water.

Even the experts should be warned not to rely on one individual data of the heating system but to try to evaluate the system in whole. It is shown that at rare distinctively sunny days the COPs reach unexpected high values. Considering the fact, that sunny day is the exception rather than the rule, in all seasons, mostly partly cloudy weather prevails. In such transient weather conditions, the heat pump, that works after definition with the simplest air/fluid heat exchanger, is the best solution as it is proved.

\section{REFERENCES}

[1] Pandey, K.M., Chaurasiva, R. (2017). A review on analysis and development of solar flat plate collector. Renewable and Sustainable Energy Reviews, vol. 67, p. 641-650, DOI:10.1016/j.rser.2016.09.078.

[2] Tian, Y., Zhao, C.Y. (2013). A review of solar collectors and thermal energy storage in solar thermal applications. Applied Energy, vol. 104, p. 538-553, D0I:10.1016/j. apenergy.2012.11.051.

[3] Powell, K.M., Edgar, T.F. (2012). Modeling and control of a solar thermal power plant with thermal energy storage. Chemical Engineering Science, vol. 71, no. 27, p. 138-145, DOI:10.1016/j.ces.2011.12.009.

[4] Dubey, S., Tiwari, G.N. (2009). Analysis of PV/T flat plate water collectors connected in series. Solar Energy, vol. 83, no. 9, p. 1485-1498, D0I:10.1016/j.solener.2009.04.002.

[5] Yang, J., Jiang, Q., Hou, J., Luo, C. (2015). A study on thermal performance of a novel all-glass evacuated tube solar collector manifold header with an inserted tube. International Journal of Photoenergy, vol. 2015, Article ID 409517, DOl:10.1155/2015/409517.

[6] Kaya, H., Arslan, K., Eltugral, N. (2018). Experimental investigation of thermal performance of an evacuated U-Tube solar collector with Zn0/Etylene glycol-pure water nanofluids. Renewable Energy, vol. 122, p. 329-338, D0l:10.1016/j. renene.2018.01.115.

[7] Sabiha, M.A., Saidur, R., Mekhilef, S., Mahian, O. (2015). Progress and latest developments of evacuated tube solar collectors. Renewable and Sustainable Energy Reviews, vol. 51, p. 1038-1054, D0l:10.1016/j.rser.2015.07.016.

[8] Morrison, G.L., Tran, N.H., McKenzie, D.R., Onley, I.C., Harding, G.L., Collins, R.E. (1984). Long-term performance of evacuated tubular solar water heaters in Sydney, Australia. 
Solar Energy, vol. 32, no. 6, p. 785-791, Dol:10.1016/0038092X(84)90253-6.

[9] Morrison, G.L., Budihardjo, I., Behnia, M. (2005). Measurement and simulation of flow rate in a water-in-glass evacuated tube solar water heater. Solar Energy, vol. 78, no. 2, p. 257-267, D0I:10.1016/j.solener.2004.09.005.

[10] Chua, K.J., Chou, S.K., Yang, M.W. (2010). Advances in heat pump systems: A review. Applied Energy, vol. 87, no. 12, p. 3611-3624, D0l:10.1016/j.apenergy.2010.06.014.

[11] Oprešnik, M. (1969). The influence of the different working means properties on the exergy loss due to the compressor heat pump processes irreversibility. (Vpliv lastnosti različnih delovnih sredstev na izgube eksergije zaradi nepovračljivosti v kompresorju pri procesih toplotne črpalke). Strojniški vestnik - Journal of Mechanical Engineering, vol. 15, no. 4-5, p. 113116. (in Slovene)

[12] Sakellari, D. Lundqvist, P. (2001). Towards energy-use optimization of a domestic heating system based on a heat pump. Strojniški vestnik - Journal of Mechanical Engineering, vol. 47, no. 8, p. 506-511.

[13] Haložan, H. (2000). Heat-Pumping Technologies. Strojniški vestnik - Journal of Mechanical Engineering, vol. 46, no. 7, p. 445-453.

[14] Hepbasli, A., Kalinci, Y. (2009). A review of heat pump water heating systems. Renewable and Sustainable Energy Review, vol. 13, no. 6-7, p.1211-1229, D0l:10.1016/j. rser.2008.08.002.

[15] Smith, D.C., Elmore, A.C. (2018). The observed effects of changes in groundwater flow on a borehole heat exchanger of a large scale ground coupled heat pump system. Geothermic, vol. 74, p. 240-246, DOl:10.1016/j.geothermics.2018.03.008.

[16] Jeong, J., Hong, T., Kim, J., Chae, M., Ji, C. (2018). Multicriteria analysis of a self-consumption strategy for building sectors focused on ground source heat pump systems. Journal of Cleaner Production, vol. 186, p. 68-80, D0l:10.1016/j. jclepro.2018.03.121. 